\title{
THE OLD BELIEVERS AND SOCIETY \\ IN THE GRAND DUCHY OF LITHUANIA IN THE EIGHTEENTH CENTURY: RELIGIOUS TOLERANCE AND ITS CAUSES
}

\section{GRIGORIJUS POTAŠENKO}

ABSTRACT. The appearance of an organized Fedoseevian community in the Grand Duchy of Lithuania in the eighteenth century was a result of the massive migration of the Old Believers (Old Ritualists), closely related to the resettlement and disturbances of the peasants and out-oftown settlers (posadskie liudi) in Russia. It was the first wave of an extensive emigration from Russia into the Baltic countries, and in particular into Lithuania. Its aftermath was the rise of the Pomorian communities (поморские обществ) of the Old Believers. In the late eighteenth century there were between 100,000 and 180,000 Old Believers (about 1.1 to 2 per cent of the total population of the 8.79 million citizens of the Republic of Poland-Lithuania). The main motives behind this emigration of the Russians in the eighteenth century were the following: (1) religious persecution of the Old Believers and the social oppression of the peasants and posadskie liudi in Russia; (2) freedom of religion for the Old Believers and more favourable social and economic conditions in Poland and Lithuania; and (3) intense eschatological feelings and impulsiveness, urging the Old Believers to avoid society and the state, in their belief dominated by the spiritual Antichrist.

This article is devoted to the issue of religious toleration in respect to the Old Believers in the GDL and its reasons. Religious tolerance as a factor conditioning the emigration and formation of a united Fedoseevian community in Lithuania has not yet been properly researched.

The first Old Believers (Old Ritualists), who came to the Republic in the latter half of the seventeenth century, were received favourably. In 1660 Old Orthodox people (древлеправославнии людие) settled in the village of Liginiškis, rejoiced exceedingly to be saved from their woes (по спасении от бед зело возвеселишася), and then they built their first sanctuary in Courland. ${ }^{1}$ The authori-

1 'Хронограф, сиречь Летописец Курляндско-литовский', Древлехранилище Пушкинского Дома. Материаль и исследования, сост. В. П. Бударагин и др. (Ленинград, 1990), р. 181. 
ties of the Duchy of Courland were also favourably disposed towards the Russian emigrants, especially during the rule of Jacob II (1642-1682). Russian settlements appeared along the Daugava between the towns of Druia and Jēkabpils. ${ }^{2}$

The Old Believers, persecuted in their homeland, were well aware of religious freedom in Poland and Lithuania. A prominent Fedoseevian spiritual father, Evstrat Vasil'ev, wrote that in 1719 the Old Believers, persecuted by Russian authorities, were forced to flee the village of Riapino (near Tartu) and many went off to the Polish Realm, for there newcomers are granted freedom to maintain the Old Church laws (мнози же в Польскую Державу отидоша, понеже тамо Древлецерковные законы содержати пришельием воля даятеся). ${ }^{3}$

The same idea was expressed in the petition of the Old Believers of Vetka for a bishop presented to the patriarch of Constantinople in 1731: 'Because of this freedom [i.e., to profess Orthodoxy] a very great number of Great Russians settled throughout Poland (Ради сей свободности великорусских людей по всей Польше населилася премногое число). ${ }^{4}$

In the eighteenth century the Russian authorities also were familiar with the spread of Old Ritualism in the Republic, where religious tolerance was greater than in Russia. On 16 October 1762 the frontier commissar Maj. Skovidov from the Pskov province informed the Senate that the Old Believers not only did not want to greet

Её императорского матерные милосердия [which they were promised on the occasion of the coronation of Catherine II on 22 September 1762] и от злодейского преступления раскаяться but also по застарелому своему изменическому упрямству и сльшать о том не желали, особливо что многие отступя от Православной кафолической церкви превратились к проклятой Раскольнической ереси, чрез лесные наставления находящихся тамо везде здешних же беглецов, той ереси лжеучителей... Ни формпостами, ни резервными

2 И. Н. Заволоко, История ичеркви Христовой (Рига, 1990), р. 154.

3 'Житие Феодосия Васильева, основателя федосеевского согласия, написанное сыном его, Евстратом, в 7250-ом году', Чтения в Императорском обществе истории и древностей Российских при Московском университете, 2 (V) (Москва, 1869), р. 92.

4 М. И. Лилеев, Из истории раскола на Ветке и в Стародубье XVII-XVIII вв., вып. 1 (Киев, 1895), pp. 121-122. 
командами в каком они ни были состоянии побегов пресечь невозможно; посылаемые ... о выдаче беглецов требования [к польской шляхте] почти безплодны остаются, ибо они о том и думать не хотят, что в требованиях Российской стороны какое удовольствие сделать и добровольно выдаче чинить, и никокмо прежних не выдают, но и вновь приходящих принимают и в своих местностях укрывают непрестающе... ${ }^{5}$

After settling in the Republic, the Old Believers formed a new religious community and in a country of victorious Counter-Reformation and soon attracted the attention of the Crown and the Catholic Church. Besides, the 1731 petition of the Old Believers of Vetka about a bishop contained an indication that after they had gone abroad they were visited at first by the Envoy Poltev and afterwards by the Bishop Antsuta.

Apparently in 1690 a state commission, headed by the secretary A. Poltev, was formed to get to know the new faith. Following the investigation of the Old Believers it stated that it did not find any schismatic traits (никакого схизматичества) and decided that they did not belong to the number of those sectaries who are dangerous to the state and church. The Old Believers were granted a charter by king Jan Sobieski on the liberty of conscience for the faith of the old Greek rite, on the residence of all ranks of persons, on the building of settlements and hermitages independent of Catholic clergy and the Jesuits. ${ }^{6}$ There are no other known sources about this charter, but in Lileev's words, its existence can hardly be doubted.

Thus, in the late seventeenth century the Old Believers of Vetka became recognized citizens of the Republic, and their religious status was institutionalized. All that was of great importance for other Old Believers in the country, and possibly not only for the Popovtsy, who in case of necessity could rely on the royal charter defining the status of their church. The attitude of the ruling circles and of the Catholic hierarchy of Poland and Lithuania was also determined by this: the Old Believers were treated as Russian immigrants - fugitives from their homeland and asylum seekers with an admissible dose of schism.

5 Российский государственный архив древних актов (hereafter РГАДА), ф. 248, оп. 113, д. 1488, л. 22-23.

6 Лилеев, ор. cit., pp. 121-122; Т. П. Короткая, Е. С. Прокошина, А. А. Чудникова, Старообрядчество в Беларуси (Минск, 1992), р. 39. 
In Russia the Old Believers experienced persecution and discrimination. In the Republic their life was much freer (гораздо привольнее). Here there was no military service, no Siberia, and no heavy taxes; there was a right of movement and trade. Of particular significance for the Old Believers was the freedom to profess their Old Faith: they were not persecuted either for crossing themselves with two fingers or for walking (processing) with the sun (хождение посолонь); and there was no immersion in water or burning of schismatic objects (ниспровержения в воду или огонь раскольнических вещей), and no various trials, and Old Ritualism was not treated as a most evil heresy (самая злая ересь).

Religious freedom for the Old Believers actually existed throughout the entire eighteenth century. Their favourable social and religious conditions in the Republic are clearly reflected in the acts, issued by the authorities and the noblemen at the time of their arrival. One such typical act related to the history of the Old Believers at Vetka and Starodub'e was published by M. I. Lileev in his study. It is a petition of the Old Believers to settle in the lands of Count Chodkiewicz and to erect a monastery in the town of Chernobyl. The petition consisted of fifteen articles, dealing with the conditions of their settlement. It covered mainly such issues as a free profession of their Old Ritualism, a right to have their own priests, monks and nuns, to build churches, monasteries, hermitages and cells. In 1771 the Count agreed with many points of the petition. $^{7}$

On the territory of present-day Lithuania such petitions are not known to the author of this paper. However, Old-Ritualist literature contains information about permission granted by the Polish authorities for the practice of Old Ritualism in the region of Suwałki and Sejny. ${ }^{8}$ It is also possible that there could have been consensual contracts on the use of land between the Old Believers and the owners of the estates there.

When the leading Lithuanian magnates - the Radvilas, Tyzenhauzes, Czartoryskis, Chreptowiczes, some of whom held important administrative posts - took in Russian immigrants on their estates, they were fully aware that a number of them were Old

7 Лилеев, ор. cit., pp. 124-125.

8 П. Голубев, 'Вести из Сувалкского района', Вестник Высшего Старообрядческого Совета в Польше, по. 2, 1930, р. 19. 
Believers. In addition, they also protected them to some extent from the violence of the Russian military squads. Between 1728 and 1755 (1758) there existed a Fedoseevian community in the Gudiškès estate of the Butlers at Dukštas, the district of Ignalina. The lively religious and cultural activities of the Old Believers there could not have been conducted without the knowledge and permission of the hosts.

Thus, in the seventeenth and eighteenth centuries the Old Believers enjoyed religious freedom in Lithuania for a period of over 130 years, while in Russia it lasted less than 25 years throughout the entire history of their existence. The difference in the conditions of the Old Believers in Russia and the GDL, particularly in the first hundred years of the history of Old Ritualism, was of great significance.

Firstly, the westward emigration of the Old Believers contributed to the dissemination of that faith in Eastern and Central Europe, and, under the conditions of severe repression of the devotees of the old creed in Russia, emigration often enabled its more prominent mentors and proponents to save themselves at least temporarily as was the case with Feodosii Vasil'ev.

Secondly, the rise of the network of the centres of Old Ritualism in the Republic and Livonia, such as Vetka, Rusanovo, Riapino, Stupilishki and Gudiškès, stimulated the development of religious teachings and practice of both the Popovtsy and the Bezpopovtsy. The evolution of the early Bezpopovism, the development of the religious teaching of the Pomorians (помориы) and the Fedoseevians and their internal polemics were significantly affected not only by the community of Vygotsk and the brothers Andrei and Semion Denisov, but also by the communities of Rusanovo (1699-1708) and of Gudiškès in the GDL and by Feodosii Vasil'ev, who afterwards became a founder of the Fedoseevian movement. Vyg was the most authoritative centre of Bezpopovism and partly of the whole Old Ritualism in the eighteenth century, and Fedoseevism was possibly the most widespread and the most influential trend in Bezpopovism. Nonetheless, the history and teaching of early Fedoseevism (up to 1711) is closely associated with the Fedoseevian communities of the Republic. The community of Gudiškès was an influential religious centre of the Fedoseevian society in the Republic, having appreciably affected the development of early Fedoseevism in Russia as well. In 1752 the so-called Polish Council (Польский собор) of Gudiškès adopted the famous Fedoseevian 
Rules, fixing the teaching of Feodosii Vasil'ev and introducing strict regulations in respect to newly weds. Consequently these Rules of the Gudiškès Council served the basis for the rules of the famous community of Preobrazhenskoe (founded in 1771) in Moscow, which afterwards became the religious centre of the Fedoseevians of Russia.

Meanwhile, the history of Fedoseevian communities in the Republic in the eighteenth century is far from being comprehensively investigated and their contribution to the formation of Bezpopovism has not yet been properly assessed.

Religious liberty in the GDL was confined only to the Old Believers and was not extended to the Russian Orthodox, who settled in Poland and Lithuania in the latter half of the seventeenth and in the eighteenth centuries. At first, people of both faiths were readily accepted for settlement, but subsequently they were treated differently. On the part of the authorities, the gentry and clergy, tolerance was accorded only to the Old Believers and not to the Orthodox. The latter were often forced to conversion.

As we know, in the Republic the seventeenth and eighteenth centuries are characterized by differences and controversies between the Orthodox and the Uniates, which arose after the Union of Brest in 1596. Rivalry between the Orthodox and the Uniate Churches, discrimination against Orthodox believers, and dissent within the Orthodox community itself, in particular in the aftermath of the conversion of influential families (the Radvilas, Chodkiewiczes, Sapiegas) to Protestantism and Catholicism (the Czartoryskis, Ogińskis, Sanguszkos), weakened the situation of Orthodoxy in the GDL. By 1701 there had remained only one Orthodox eparchy that of Mogilev - instead of the former four. ${ }^{9}$ Protestant countries like Prussia, Sweden, Denmark, England and Orthodox Russia were even in competition with one another in defending the interests of the adherents of different faith in Poland and Lithuania. In the search for a resolution of this problem, Polish and Lithuanian noblemen entered the fray, and that often damaged their own interests. Orthodox believers were increasingly forced to convert to the Uniate Church. Between 1700 and 1747 the Catholic nobility, basing itself on the right of patronage, deprived the Orthodox of 164

9 J. Tazbir, Historia kościoła katolickiego w Polsce (1460-1795) (Warsaw, 1966), p. 167. 
churches (according to other sources, 240), and five monasteries and handed them over to the Uniates; by the middle of the eighteenth century the Orthodox had only 130 churches in Belorussia. ${ }^{10}$

Therefore religious coercion was experienced not only by the local Orthodox but also by Orthodox Great Russians, who arrived constantly in the Republic. The latter were more stable in their religious allegiances and were not willing to depart from their Orthodox tradition. Often they preferred to adopt Old Ritualism, conditions for which were more favourable there. A typical case is that of the Popovets clergyman Zakhar Grigor'ev, who moved from the GDL to the Old Ritualist sloboda (a village of free peasants) of Radul' in Russia in the 1750s. He stated that his uncle Mikhail and his father Grigorii, having emigrated from Russia, had been Orthodox priests of the church of the village of Kodolovo in the Polotsk estates of Duke Radvila until the conversion of their church into a Uniate one. Then his father accepted Old Ritualism and became a priest in the raskol fashion (по раскольничемy) in the sloboda Spasovaia in the Gomel district. ${ }^{11}$

It should be noted that fugitive Russians used to change their faith in 'more peaceful' ways - by mixed marriages with Uniates, Catholics or Old Believers. ${ }^{12}$ In this way the government of the Republic encouraged the spread of Old Ritualism even among the Orthodox Russian emigrants by extending its patronage to the Old Believers and by its intolerance for Orthodoxy.

A question naturally suggests itself: why were Russian Old Believer emigrants treated favourably by the Republic's authorities, nobility and the Catholic Church? It should be taken into account that the Old Believers appeared at the climax of the CounterReformation, when it seemed that outbreaks of religious intolerance and repression had reached their peak. In 1640 the Lutherans were ousted from Vilnius after their church had been committed to the flames for the third time; in 1658 the Arians were expelled from the Republic, and in 1717 the Sejm decided to limit the political rights of the dissidents. ${ }^{13}$ According to the cultural sociologist Vytautas Kavolis, the Counter-Reformation in the GDL meant a replacement

${ }^{10}$ История Белорусской ССР (Минск, 1977), p. 79; Lietuvos istorija пио seniausiu laiku iki 1917 m., t. 1 (Vilnius, 1985), p. 181.

11 Лилеев, ор. cit., pp. 123-124.

12 РГАДА, ф. 248, оп. 7, кн. 397, л. 1171-1190.

13 J. Kregždè, Reformacija Lietuvoje (Chicago, 1980), pp. 193-194. 
of the 'modernist' system, formed in the Lithuanian culture in the sixteenth century, by a 'medieval' culture, in which the dominating ideology acquired a functional priority in respect to state laws. Therefore the former laws of the minorities underwent revision. ${ }^{14}$

However, the entrenchment of the new system proceeded slowly and was not all-pervading in Lithuania. Besides, these repressive measures did not cover the Old Believers, and the tolerance for them embraced both their religious canons and their civil rights.

In contrast to the Arians and partially to the Orthodox and Protestants, a sympathetic positive attitude to the various Old Ritualist communities was a convincing proof of the Republic as a haven of tolerance in Europe. As has already been mentioned, after a special investigation of the Old Believers at Vetka in the 1690s, the secular and ecclesiastical authorities of the Republic came to a conclusion that the Old Believers were not dangerous sectaries. The Old Believers, both the Popovtsy and the Bezpopovtsy, who expounded Christian dogmas seemed more acceptable in Poland and Lithuania than Kazimierz Leszczyński, burned at the stake in 1689 for sympathizing with atheism, or the Great Polish nobleman Andrzej Grudzyński (d. 1678), who was indifferent to religion and stated that 'I don't profess any faith, but when I get to heaven, I'll choose the best religion and become a believer'. ${ }^{15}$

The Old Believers seemed more acceptable in the Republic than the Arians, expelled from the country between 1658 and 1660, who rejected the main dogma of the Catholic theology - the Trinity, and according to the law of the Sejm were considered professors of a dangerous heresy. ${ }^{16}$ It is also noteworthy that the Old Believers were foreigners and that their faith hardly ever spread among other people at the expense of other religions either in the seventeenth century or later. According to a law of 1658 citizens were forbidden to abandon Catholicism. In this respect the situation of the Old Ritualist community in the Republic resembled that of the Jews, Muslims and Karaites, and it differed from Calvinism, which at one time profoundly attracted the privileged nobility, and from Luther-

${ }^{14}$ V. Kavolis, Žmogus istorijoje (Vilnius, 1994), pp. 397-398.

${ }_{15}$ Quoted by Tazbir, Historia kościoła katolickiego w Polsce (1460-1795), p. 167.

16 J. Tazbir, Netolerancja wyznaniowa $i$ wygnanie arian (Warsaw, 1957), p. 39 . 
anism, which left its imprint on the bourgeoisie, inconsiderable in number at that time.

At first the Old Believers settled mostly in the periphery mainly in the north-western and eastern lands of he Republic. The majority of them were peasants and inhabitants of small towns. Enjoying freedom of religion and being free people (though some of them sometimes became serfs) and immigrants, they did not have any political rights, which in the estate society belonged to the nobility and the Catholic clergy. Therefore the Old Believers did not aim and could not claim to join in the political life of the Republic. On the other hand, they had no way to limit the influence of the Catholic hierarchy on the masses of the citizens and subjects of the Republic.

The social activity of the Old Believers became more significant in the second half of the eighteenth and early nineteenth centuries, when they started publishing their religious and polemical books in the printing houses of Vilnius, Grodno, Suprasl and Pochaev. ${ }^{17}$

Thus, the religious acceptability of the Old Believers accounted to some extent by their social and territorial insulation in society. Ideological and economic factors should also be taken into consideration. Mercilessly persecuted in their own country in the course of a century, the Old Believers were met by at least a part of the society of the Republic as dissidents of hostile Russia and opponents of the Russian Orthodox Church. Frequent overt searches for emigrants by Russian troops on the territory of the Republic threw not only the Old Believers, but also the Polish and Lithuanian landowners into panic and aroused sympathy for their cause. Experiencing that and suffering material losses, local landowners, enjoying their golden liberty, began defending the Old Believers or sending them to the interior of the country.

The gentry was unwilling to extradite Russian fugitives, saying that they were Old Believers persecuted in their own country and, more often, their own subjects, arrested by Russian troops. Frequent frontier incidents became a political issue of long standing. In the 1750s the Russian colonel Nikolai Panov, sent to the Republic for the arrest of fugitives, informed his authorities that the Polish

${ }^{17}$ In greater detail about publishing, see А. В. Вознесенский, И. П. Мангилев, И. В. Починская, Издательская деятельность старообрядиев (1701-1918). Материаль к словарю (Екатеринбург, 1996); Z. JarosziewiczPieresławcew, Starowiercy $w$ Polsce $i$ ich księgy (Olsztyn, 1995). 
and Lithuanian landowners agreed to give away only fugitive soldiers, criminals and house serfs, but not peasants, whom they did not consider deserters. Panov objected stating that 'дезертир' was not a Russian or a Polish word, it was a German word meaning 'any type of runaway' (беглеи всякий) in Russian; all landowners selected house serfs from their peasants, and others were dismissed as peasants. However, these objections were not taken into account either by the Poles or by the Lithuanians. The Russian colonel found scores and hundreds of fugitive soldiers in Grodno, Białystok, Warsaw, Vilnius and other places. When Panov presented an order from the Lithuanian chancellor Prince Czartoryski, requesting the deputy palatine of Vilnius to requisition fifty fugitive soldiers, the deputy replied: 'This is only our Polish politics' (Эmo только наша польская политика).

Livonia, a dependency of the Republic, was settled almost wholly by Russian refugees, overwhelmingly Old-Believer schismatics. ${ }^{18}$ When Panov arrived in Livonia, many villages, inhabited by Russian fugitives, emptied, since people fled to the woods. The officials sent for them, twenty people were caught, but only one or two were handed over, while the relatives of the Old Believers were kept and were allowed to return; those who informed Panov about the fugitives were punished by the officials. The priest Askirka was in charge of forty villages, inhabited by Russian emigrants. He declared that he even did not want to look at the decree of Polish ministers, and as long as he was not paid back 100,000 thalers and had 90 runaway persons returned, he would not give a single Russian; he also threatened revenge on Panov. ${ }^{19}$

The Old Believers made up ca. 1.1-2.0 per cent of the total number of $8,790,000$ of the population of the Republic. On the territory of the country there could have lived ca. 100,000-180,000 Old Believers by the year 1772. By 1791 that number could have risen from 100,000 up to 180,000 Old Believers, taking into account the loss of a third of the territory, which was ceded to Russia, and new waves of immigrants as well as the natural increase in population. On the whole, data given by contemporaries and later re-

${ }^{18}$ С. М. Соколов, История России с древнейших времен, кн. 12 (Москва, 1964), pp. 220-221.

${ }^{19}$ Ibid., p. 221. 
searchers on the number of the Russians on the territory of the GDL were based not on statistics, but on more or less realistic opinions of official and individual observers. Therefore the numbers varied greatly - from three to ten times. Thus, Count N. Panin considered that in 1772 there were over 300,000 Russian nationals in the Republic bar their generation from the beginning of the emigration. ${ }^{20}$ In Panin's counts the Old Believers and the Nikonites were not divided into separate groups. The contemporaries sometimes indicated unbelievable numbers of fugitive Russians in the Republic: they allegedly made up a very great multitude (превеликое множесто), almost a million, according to the court councillor A. Svechin, who visited the Republic on business in the late 1750s and early $1760 \mathrm{~s}^{21}$ The Old Ritualist merchant M. Yakovlev from Toropets informed the Senate that in the Republic the number of Russians was no less than 1.5 million males ( $\mathrm{sic}$ ), apart from households... in Poland and in the Turetsk district... in Poland alone there are more than one million. ${ }^{22}$ According to the Polish historian Tadeusz Korzon in 1791 there were approximately 100,000 Old Believers in the Republic after the First Partition. ${ }^{23}$ Another investigator considered that at the end of the eighteenth century there were about 140,000 Old Believers in the GDL. ${ }^{24}$

The economic motive, though not the most important, was nevertheless a significant factor, conditioning toleration of the Old Believers. In the course of over a hundred years, starting from the middle of the seventeenth century, there was a great need for the labour force as a result of a catastrophic decline of economy and an almost twofold reduction of the population in the Republic. The benevolent attitude of Polish and Lithuanian landowners to Russian dissident immigrants, for instance, to the Fedoseevians, adhering to strict ascetic rules and maintaining limited contacts with the outside 'world of the Antichrist', is perplexing. However, that seems so only at first glance. The point is that that in the eighteenth century

20 Сборник Императорского руского исторического общества, 1891, t. 72 , no. 639 .

21 РГАДА, ф. 248, оп. 113, ж. 647, л. 7-9.

22 РГАДА, ф. 248, оп. 113, д. 1491, л. 138-139.

${ }^{23}$ T. Korzon, Wewnętrzne dzieje Polski za Stanisława Augusta (1764-1794), t. 1 (Cracow-Warsaw, 1897), p. 320.

${ }^{24} \mathrm{~W}$. Wiełhorski, 'Stosunki narodowościowe, wyznaniowe i językowe', Dzieje Wielkiego Księstwa Litewskiego, 1953), p. 221. 
the Polish and Lithuanian landowners as well as those of Bohemia or Austria did not care much about the religious beliefs and the internal structure of dissident communities. Driven from their native places, the Old Believers, the people of Hernnhut and Mennonites were welcomed by many landowners, which used to give them shelter even if that complicated their relations with the dominating Church. Old Believers, such as the Fedoseevians living at Nevel (about 1,300 people), not only paid lord Kunitskii their quitrent regularly but also were skilful craftsmen and could clear and plough wastelands well. That was a result of the internal construction of the Old Ritualist communities, labour consciousness and a rational organization of their team work. In this respect, the tolerance of Polish and Lithuanian landowners and managers of the estates of the Catholic Church could simply be accounted for by sheer sober estimate.

Thus, tolerance for the Old Believers in Lithuanian society was based on their religious acceptability, immigrant status, and economic and political interests of the landowners; in the eighteenth century that was supplemented by the favourable influence of the Enlightenment ideas - Western European rationalism and anticlericalism.

On the other hand, while speaking about the religious tolerance for the Old Believers one must not forget that that tolerance was not limitless. At that time tolerance in the Republic was as rare a virtue as in other European countries. In the seventeenth and eighteenth centuries Catholics and Protestants, Orthodox and Uniates, the Popovtsy and the Bezpopovtsy, Jews and Muslims, were almost all convinced that only their faith was the most direct way to salvation. Each of these religions could be extremely intolerant both of each other and also of any deviation within its own doctrine, and that could lead to conflicts and fragmentation. Correspondingly, strict and even cruel penalties for any religious transgressions were deemed necessary and unavoidable. Defenders of the liberty of conscience were few. In the late seventeenth century many reasoned like Jan Brzóska having laid an information against Kazimierz Leszczyński in 1688: 'Nothing ruins a kingdom during an interregnum as sects do'.25

${ }^{25}$ Quoted by J. Jurginis, Istorija ir kultūra. Kultūros pažangos apybraižos (Vilnius, 1984), pp. 141-142. 
However, in the Republic, in which there was no strong centralized power, anarchy (анархия) and golden freedom (золотая свобода) were enjoyed by the nobility and clerical courts were too weak to establish their supremacy, it was impossible to introduce one religion. In the words of Norman Davies, "No one could overturn the Catholic establishment, and no one could realize its absolute pretensions'. ${ }^{26}$ In the Republic there were no religious wars, no St Bartholomew's Day Massacre, and the unrestricted rights of the nobility in a way prevented the rise of religious fanaticism. In the Republic the Old Believers found a relatively safe haven and enjoyed a relative freedom of religion. Here strict regulations of Tsaritsa Sophia did not exist, there was no religious oppression, often resulting in self-immolation by Old Believers, and no state policy of burning their churches and old books.

\section{Author Details}

Head of the Research Programme of Russian Old Believers Dr Grigorii Potashenko graduated from the University of Vilnius and did his doctoral studies at the Faculty of History of the same University. His research interests are Old Belief (Ritualism) in Eastern and Central Europe and national minorities in Lithuania. Address: Centre for Stateless Cultures, Faculty of History, University of Vilnius, Universiteto 7, Vilnius LT-2734, Lithuania

Email: grigorijus.potasenko@if.vu.lt

\section{SENTIKIAI IR LIETUVOS DIDŽIOSIOS KUNIGAIKŠTYSTĖS VISUOMENĖ XVIII A.: RELIGINÉ TOLERANCIJA IR JOS PRIEŽASTYS}

Santrauka

\section{GRIGORIJUS POTAŠENKO}

Sentikių fedosėjininkų bendrijos LDK XVIII a. susiformavimas buvo masinès rusų sentikių emigracijos iš Rusijos rezultatas. Pagrindiniai emigracijos motyvai buvo: sentikių religinis persekiojimas bei diskriminacija; valstiečiu bei posados žmonių socialiniai suvaržymai; žinios ir gandai apie bajorų, Katalikų bažnyčios bei karališkų dvaru LDK palankumą persikèlèliams; pagaliau, intensyvus eschatologinis jausmas, skatinęs sentikius

${ }^{26}$ Norman Davies, God's Playground. A History of Poland, vol. 1 (Oxford, 1981), p. 200. 
vengti visuomenès ir valstybės, kuriuose, jų manymu, ỉsigalëjo dvasinis antikristas. Šiame straipsnyje nagrinejjama religinès tolerancijos sentikių atžvilgiu LDK visuomenejje problema.

Sentikių padètis Lenkijos ir Lietuvos valstybeje, priešingai negu Rusijoje, buvo gana anksti legalizuota - tikètina, kad tai îvyko XVII a. pabaigoje. Tikybos laisve sentikiai šalyje naudojosi visą XVIII a. Svarbiausieji šio pakantumo veiksniai: 1) salyginis sentikiu, nepriklausiusiu „,valstybei ir bažnyčiai pavojingiems sektantams“, religinis priimtinumas; 2) po dvieju demografiniu krizių bei užsitęsusio ekonominio nuosmukio, prasidèjusio XVII a. viduryje ir užtrukusio iki XVIII a. vidurio, vietiniai bajorai buvo ypač suinteresuoti naujų atvykèliu iš užsienio antplūdžiu; 3) lietuviškoje to meto visuomenejje sentikiai buvo traktuojami kaip tam tikrą politini pasitikejimą keliantys Rusijos religiniai disidentai, verti moralinės užuojautos; 4) sentikiu socialinis ir teritorinis atskirumas šalyje; 5) XVIII a. antroje pusejje pakantumą LDK visuomeneje galèjo skatinti ir plintančios iš Vakarų Europos Švietimo idejos: racionalizmas ir antiklerikalizmas.

Socialiniu-teisiniu požiūriu sentikius Respublikoje galima traktuoti kaip atskirą luomą (grupę). $1772 \mathrm{~m}$. Respublikoje galèjo gyventi 100-180 tūkstančių sentikių. $1791 \mathrm{~m}$. Respublikos teritorijoje po pirmojo padalijimo gyveno 100-180 tūkstančių sentikių arba 1,1-2 \% visų šalies gyventojŭ, kurių skaičius tuo metu siekè $8,79 \mathrm{mln}$.

Received 20 June 2001 